\title{
Tanggung Jawab Atas Kebijakan Yang Diterapkan Oleh Perusahaan Induk Kepada Perusahaan Anak Yang Berakibat Pada Timbulnya Suatu Kerugian
}

\author{
Made Gede Niky Sari Sumantri1,
}

1Fakultas Hukum Universitas Udayana, E-mail: sumantrinikky@gmail.com

\begin{tabular}{l}
\hline Info Artikel \\
\hline Masuk :31 Januari 2020 \\
Diterima : 2 Februari 2020 \\
Terbit : 30 April 2020 \\
Keywords : \\
Legal liability, parent company \\
policy, subsidiaries, compnies \\
grup, \\
\\
Kata kunci: \\
Tanggung Jawab, Perusahaan \\
Induk, Perusahaan Anak \\
Kerugaian \\
Corresponding Author: \\
Made Gede Niky Sari \\
Suamntri, E-mail: \\
\end{tabular}

\begin{abstract}
Liability to the parent company for policies implemented by subsidiaries that result in losses with third parties is a major problem in the practice of group. This problem This problem is due to absence of legislation that specifically regulate of the company group, the regulatory framework of the realationship the parent and it's subsidiaries in the group companies is use Corporate Law. The incorporation of the company's subsidiary in the group does not abolish the legal status of a subsidiary. Parent companies in the group company contractions have immunity over the implementation of the principle of limited liability. the purpose of writing this journal is to know, how is the assignment legal liability to the parent company for the policies applied to the subsidiary companies resulting in a loss to a third party and how to anticipate control without legal liability the parent company for its policies that impact the economic insecurity of the subsidiary in the construction of group companies. The research that the author uses is normative legal research. From this research, assigning legal liability to the parent company through the implementation of policies implemented by the subsidiary is certainly seen from the fault that cause losses. One effort that can be done to anticipate control without legal liabilty of the parent companies it's Make Charter Corporate Relations and Between Subsidiaries or make agreement control between the parent company and subsidiary.
\end{abstract}




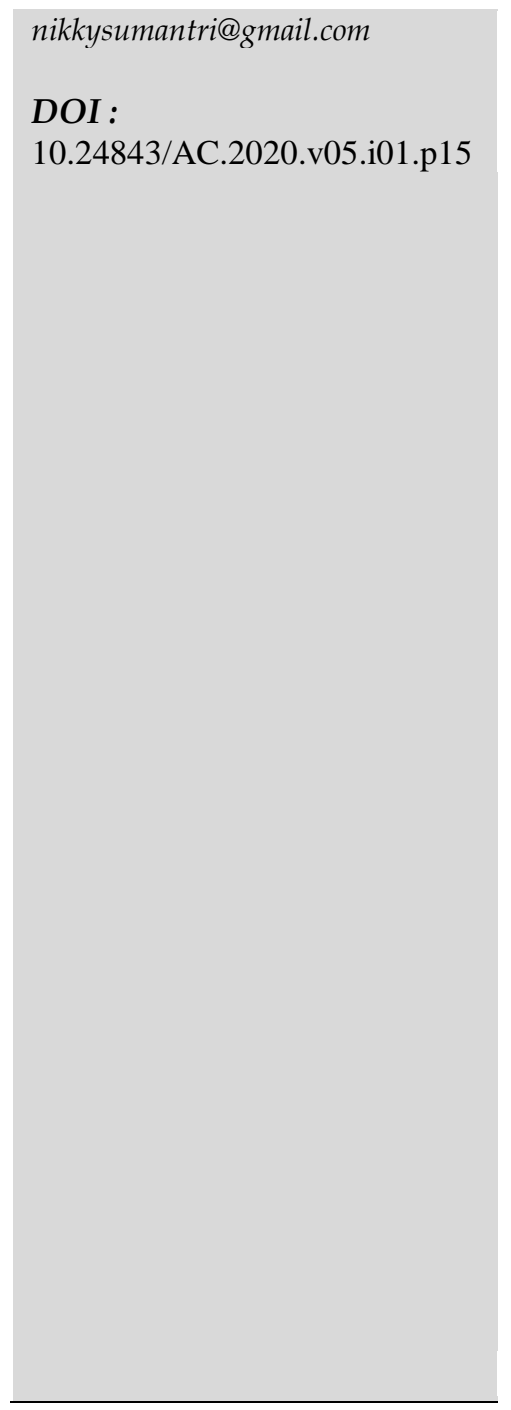

masih menggunakan hukum perseroan. Tergabungnya perusahaan anak(subsidiary) kedalam kontruksi perusahaan grup (holding company) tidaklah menghilangkan status badan hukum anak perusahaan (subsidiary). Perusahaan Induk (parent company) sebagai pimpinan sentral di dalam konturksi perusahaan grup (holding company) ini memiliki imunitas atas berlakunya prinsip limited liability, yaitu bertangung jawab sebatas hanya sebesar saham yang dimilikinya. Penulisan ini tujuannya untuk mengetahui bagaimanakah pembebanan tanggung jawab perusahaan induk (parent company) atas kebijakan yang diterapkan kepada perusahaan anak (subsidiary) sehingga berakibat timbulnya suatu kerugian, dan bagimanakah mengantisipasi pengendalian tanpa tanggungjawab dari perusahaan induk terhadap kebijakan yang berdampak pada ketidakmandian secara ekonomi anak perusahaan dalam kontruksi perusahaan grup. Jenis Penelitian yanggdigunakan oleh penulis adalah penelitian hukum normatif. Dari penelitian ini diperolah kesimpulan, bawha pembebanan tanggung jawab terhadap perusahaan induk (parent company) melalui penerapan kebijakan yang dilaksanakan oleh perusahaan anak (subsidiary) tentunya dilihat dari adanya kesalahan/kelalain (perbuatan melawan hukum) yang menyebabkan adanya kerugian, maka perusahaan induk (parent company) dapat dimintai pertanggungjawaban. Usaha yang dapat dilakukan untuk menghindari pengendalian tanpa tanggung jawab dari perusahaan induk (parent company terhadap kebijaknnya yang berdampak ketidakmandian secara ekonomi anak perusahaan (subsidiary) dalam kontruksi perusahaan grup (holding company) adalah membuat CharterHubungan Korporasi Dengan Perusahaan Anak (subsidiary) atau melalui suatu perjanjian pengendalian antara perusahaan induk dan perusahaan anak.

\section{Pendahuluan}

Dunia bisnis di Indonesia pada masa sekarang medirikan badan usaha yang berwujud perseroan terbatas-(PT) mejadi salah satu pilihan yang paling banyak diminati bagi para pengusaha ataupun investor dalam menjalakan usahanya. Perseroan terbatas (PT) adalah persekutuan modal dengan wujud badan hukum yang pendirianya berdasarkan perjanjian/agreement untuk menjalakan kegiatan usaha, dan seluruh modal dasarnya terbagi atas saham-saham(divided into shares) yang wajib diambil oleh para pendirinya tersebut. ${ }^{1}$ Selanjutnya dalam praktik bisnis perseroan terbatas telah mengalami perkembangan, dapat dilihat semakin banyaknya suatu badan usaha yang mendirikan perusahaan grup (holding company) yang mana terdiri dari beberapa perseroan, seperti contohnya Salim Grup, Mnc Grup, Semen Indonesia Grup Dan Lain-Lain.

Pendirian perusahaan grup di Indonesia dianggap memiliki peranan untuk menghidupkan roda perekonomian dalam negeri, karena sebagian besar di Indonesia

${ }^{1}$ Bonifaius Aji Kuswantoro, 2016, Keuntungan \& Resiko Menjadi Direktur, Komisari, Dan Pemegang Saham, PT Visimedia Pustaka, Jakarta, hlm. 5-6 
perusahaan grup berawal dari bisnis perdagangan(trading). ${ }^{2}$ Pembentukan suatu perusahaan grup (holding company) ditujukan untuk menghadapi persaingan secara global di dunia bisnis dalam mengembangkan wilayah bisnisnya. Salah satu indikatornya adalah telah memiliki market power yang besar dari penguasaan pasar, yang mana produk perusahaan telah menjadi andalan atau mendominasi. Kemunculan perusahaan grup-(company holding) dapat ditandai dari adanya perubahan struktur organisasi perusaahan tunggal dengan bisnis sederhana kemudian meningkat menjadi perusahaan grup(holding company) dengan model yang lebih kompleks dan rumit.

Difinisi dari perusahaan grup-(company holding) tidak diatur/termuat di dalam ketentuan Undang-Undang No.40Tahun2007 Tentang Perseroan Terbatas (PT). Menurut dari pendapatnya Emmy Simanjuntak yang dikutip dari bukunya Sulistiowati, perusahaan grup-(holding company) merupakan gabungan dari beberapa perusahaan yang memiliki keterikatan satu sama lainnya secara yuridis mandiri sebagai satu kesatuannekonomi, dan patuh pada satu pimpinan yaitu perusahaan induk (parent company) sebagai pimpinan perusahaan. ${ }^{3}$ Perkembangan perusahaan grup (holding company) di Indonesia dalam kegiatan bisnis dan usaha tidak terlepaskan dari ligitimasi peraturan perundang-undangan. Undang-Undang No.40 Tahun2007 Tentang Perseroan Terbatas (PT), telah mengizinkan kepada perseroan untuk memiliki/mempunyai saham persero lainnya. Ketentuan tersebut termuat di dalam ketentuan Pasal 7Ayat(1) UU No.40Tahun2007 Tentang Perseroan Terbatas (PT), bahwa memperbolehkan kepada seseorang/subyek hukum untuk mendirikan perseroan.

Menurut pendapat dari Sulistiowati, memorial dari uraian pasal tersebut menjabarkan bahwa yang dimaskud dengan seseorang/subyek hukum adalah orang perseorangan (natuurlijk persoon), baik WNI (warga negara Indonesia) ataupun WNA (warga negara asing) atau badan hukum (rechts persoon) PMDN atau asing PMA. Sulistiowati juga menambahkan bahwa memorial dari uraian pasal tersebut, tidak mengarah secara khusus sebagai wujud pengaturan terhadap perseroan grup-(holding company), namun tindakan hukum suatu perseroan terbatas(PT) untuk mendirikan perseroan lain berimplikasi kepada munculnya keterkaitan antara dua perseroan tersebut melalui kepengusaan saham. ${ }^{4}$ Pengertian diatas menunjukan bahwa jalinan keterkaitan yang terjadi diantara perusahaann induk (parent company) dengan perusahaannanak (subsidiary) di dalam kontruksi perusahaanngrup-(holding company) didasarkan oleh kepemilikan saham mayoritas perusahaan induk (parent company), sehingga perusahaan induk (parent company) mejadi pimpinan sentral yang memiliki kekuasaan untul bertindak mengkoordinasikan serta mengendalikan perusahaan anak (subsidiary) dalam satu kesatuan menejemen bagi terciptanya tujuan kolektif perusahaan grup/(holding company).

Sebuah perusahaan dapat menjadi perusahaan induk (parent company) dalam perusahaan grup (holding company) apabila memiliki saham mayoritas atau lebih dari $50 \%$ saham perusahaan anak (subsidiary). Atas kepemilikan saham mayoritas tersebut,

2 Sulistiowati, S. (2012). Doktrin-doktrin Hukum mengenai Tanggung Jawab Hukum

dalam Perusahaan Grup. Jurnal Hukum Bisnis, 31(3), 5-25.

3 Sulistiowati, 2013, Tanggung Jawab Hukum Pada Perusahaan Grup Di Indonesia, Erlangga, Jakarta, hlm. 19

4 Ibid 
perusahaan induk (parent company) mempunyai kewenangan dalam pengembangan kebijakan, pengelolaan strategi bisnis, dan melakukan pengawasan atas aspek oprasional bisnis perusahaan. Maka dengan demikian, perusahaan induk (parent company) mendapatkan manfaat yang lebih menguntungkan jika dibandingkan dengan melakukan kegiatan bisnis perusahaan biasa/tunggal. Pembentukan perusahaan grup (holding company) ini mengacu kepada realitas bisnis yang dikendalikan oleh perusahaan induk(parent company) sebagai pimpinan sentral. Melalui kepemilikan sahan mayoritas dari perusahaan induk (parent company) terhadap perusahaan anak (subsidiary) tersebut, memungkinkan perusahaan induk (parent company) mengendalikan dan medominasi kepengurusan perusahaan anak-(subsidiary), sehingga orientasi kepentingan ekonomi dari perusahaan anak (subsidiary) sepenuhnya mengarah untuk mendukung kepentingan perusahan grup (holding company). Hal ini berimplikasi terhadap ketidakmandirian yuridis perusahaan anak(subsidiary), karena perusahaan anak (subsidiary) wajib menjalakan intruksi perusahaan induk (parent company).

Kontruksi pengaturan ini memberikan peluang kepada perusahaan induk (parent company) untuk menyalahgunakan kewenangan kontruksi perusaahaan grup (holding company) atau memanfaatkan keadaan hukum dalam menjalakan kegiatan usahanya. Penyalagunaan kontruksi perusahaan grup(holding company) ini menimbulkan suatu kerugian kepada perusahaan anak (subsidiary) atau juga yang disebut sebagai opportunity lost. Sementara itu, perusahaan induk (parent company) sebagai pemilik saham mayoritas perusahaan anak (subsidiary) mendapat perlindungan dengan adanya prinis limited liability atau juga disebut sebagai tanggung jawab terbatas perseroan. Sehingga dengan belakunya prinsip hukum limited liabillity perusahaan induk (parent company) hanya bertanggungjawab sebesar nominal saham yang dimiliki pada perusahaan anak-(subsidiary), jika perusahaan anak (subsidiary) tidak bisa memenuhi dan meyelesaikan tanggungjawab hukum kepada pihak ketiga.

Berlakunya prinsip limited liablity menciptakan insetif perbuatan hukum beresiko tinggi yang memungkinkan perusahaan induk (parent company) menghindari tanggung jawab dengan cara mengektralisasikan resiko kepada perusahaan anak (subsidiary). Apabila segala sesuatunya berjalan tidak baik atau menjadi buruk, perusahaan induk (parent company) dapat mendirikan perusahaan anak baru (new subsidiary) dan perusahaan anak subsidiary) yang tidak mampu membayar utang kepada kreditur dapat menyatakan dirinya bangkrut. ${ }^{5}$ Penyalahgunaan kontruksi perusahaan grup (holding company) ini sangat merugikan kepentingan pihak ketiga perusahaan anak, yang dalam hal ini terdiri dari pemilik saham minoritas, kreditur, maupun pekerja perusahaan anak. Tanggungjawab hukum(legal liability) dalam pratik perusahaan grup (holding company) mejadi suatu permasalahan, karena hal ini disebabkan belum adanya peraturan perundang-perundangan yang khsusus dalam mengatur perusahaan grup(holding company), sehingga kerangka pengaturan terhadap ketertarikan perusahaan induk (parent company) dengan perusahaan anak (subsidiary) dalam perusahaan grup(holding company) masih menggunakan hukum perseroan. Berdsarkan latarbelakang tersebut dirumuskan masalah sebagai berikut: 
1. Bagaimanakah pembebanan tanggung jawab terhadap perusahaan induk atas kebijakan yang diterapkan kepada perusahaan anak sehingga berakibat pada timbulnya suatu kerugian?

2. Bagimanakah upaya untuk mengantisipasi pengendalian tanpa tanggung jawab dari perusahaan induk atas kebijakan kepada perusahaan anak sehingga terhindar dari timbulnya suatu kerugian?

\section{Metode Penelitian}

Jenis penelitian yang digunakan dalam tulisan ini adalah penelitian hukum normatif, yang berawal dari adanya kekosongan norma terhadap pembebanan tanggung jawab perusahaan induk (parent company) atas kebijakan yang diterapkan kepada perusahaan anak-(subsidiary) sehingga berakibat timbulnya suatu adanya kerugian. Pendekatan permasalahan melalui pendakatan perundang-undangann(statute approach) dan pendekattan analisis konsep hukum (analytical conceptual approach). Penelitian ini dilakukan dari bahan kepustakaan, seperti peraturan perundang-undangan, dan literatur-literatur yang berkaitan dengan isu-isu yang akan dipecahkan. Hal ini dimaksudkan untuk memperoleh infomasi yang relevan dari berbagai aspek, sehingga akan sangat membantu untuk memecahkan permasalahan dalam penelitian ini.

Penelitian ini bersumber dari tiga jenis bahan hukum yaitu,aperaturan perundangundangan sebagai bahan hukum primer, berupa literatur-literatur/buku-buku, karya ilmiah serta artikel-artikel, maupun dari pendapat-pendapat ahli dibidang hukum sebagai bahan hukum sekunder, dan kamus hukum sebagai bahan hukum terseir. Tehnik penelusuran bahan hukum menggunakan tehnik sistem kartu dengan mencatat bahan-bahan yang relevan terkait permasalahan, dan kemudian bahan-bahan tersebut dikumpulkan untuk dianalisis dengan teknik deskriptif.

\section{Hasil Dan Pembahasan}

\subsection{Pembebanan tanggung jawab terhadap induk perusahaan atas kebijakan yang diterapkan kepada perusahaan anak sehingga berakibat timbulnya suatu kerugian.}

Pembebanan tanggung jawab terhadap perusahaan induk (parent company) atas kebijakan yang diterapkan kepada perusahaan anak (subsidiary) sehingga berakibat timbulnya suatu kerugian adalah bentuk dari perlindungan hukum terhadap pihak ketiga perusahaan anak. Tanggungjawab hukum pada perusahaan induk (parent company) di dalam perusahaan grup (holding company) ini, mensyaratkan harus terpenuhinya kausalitas adanya perbuatan melawan hukum dan/atau adanya unsur kelalain atas pemenuhan suatu prestasi dalam suatu perjanjian yang terbukti menimbulkan suatu kerugian kepada orang lain. Bagaimanapun realitas bisnis antara perusahaanninduk (parent company) dan perusahaann anak-(subsidiary) di dalam kontruksi perusahaan grup (holding company) tidak terlepas dari adanya motif hubungan kerjasama diantara dua dan/atau lebih badan hukum mandiri. Untuk itu, setiap perbuatan yang menyebabkan suatu kerugian, mewajibkan kepada seseorang yang melakukan kesalahan mengganti kerugian terbsebut. ${ }^{6}$

\footnotetext{
${ }^{6}$ Ibid, hlm. 125
} 
Ada beberpa hal terhadap adanya pengendalian dan dominasi dari perusaahan induk kepada perusahaan anak (subsidiary) yang merupakan anggota kelompok perusahaan grup yaitu sebagi berikut.7 Pertama, Kepemilikan Saham Mayoritas Perusahaan Anak Oleh Perusahaan Induk (parent company). Kemepilikan saham dalam jumlah mayoritas perusahaan anak (subsidiary) ini, memberikan kewenangan kepada perusahaan induk (parent company) untuk mengendalikan dan mengontrol berbagai aktivitas di antara perusahaan anak (subsidiary), dengan cara mengkoordinasikan aktifitas perusahaan anak (subsidiary) menjadi satu kesatuan menejemen dalam kontruksi perusahaan grup. Kepemilikan saham mayoritas perusahaan anak (subsidiary) oleh perusahaan induk (parent company) ini termuat secara jelas di dalam anggaran dasar perusahaan anak (subsidiary). Salah satu fungsi kepemilikan saham mayoritas oleh perusahaan induk (parent company) ini adalah Zeggenschapsfunctie yaitu memberikannhak suara untuk mengontrol dan mengendalikan perusahaan anak (subsidiary) melalui Rapat Umum Pemegang Saham (RUPS) ditujukan untuk menunjang Baleggingsfunctie sebagai satu kesatuan ekonomi dalam kontruksi perusahaa grup(holding company). Kedua, Rapat Umum Pemegang Saham (RUPS). Melalui Rapat Umum Pemegang Saham (RUPS) perusahaan anak (subsidiary), perusahaan Induk (parent company) dapat menetapkan anggota direksi atau dewan komisaris perushaan anak (subsidiary) dan menetapkan kebijakan serta strategi-strategi bisnis jangka panjang (business plan) untuk dapat mendukung pencapaian tujuan perserusahaan grup(holding company). Dalam recana strategik ini, perusahaan induk (parent company) melalui direksi menentukan kebijakan perusahaan terkait dengan visi, misi, budaya, dan strrategi perusahaan. Penetapan kebijakannoleh perusahaan induk (parent company) wajib diikuti atau dijalankan oleh perusahaan anak yang merupan anggota dalam perusahaan grup. ${ }^{8}$

Ketiga, Penetapan Anggota Direksi Dan/Atau Dewan Komisaris. Melalui pengusaan saham mayoritas perusahaan anak (subsidiary) oleh perusahaan induk (parent company), memberikan kewenangan perusahaan induk (parent company)untuk menetapkan anggota direksi dan/atau dewan komisaris pada perusahaan anak(subsidiary), yang secara tidak langsung merupakan bentuk pengendalian dan dominasi di dalam kegiatan oprasional perusahaan anak (subsidiary). Secara tidak langsung perusahaan Induk (parent company) juga dapat memantau perkembangan dari perusahaan anak (subsidiary). Keempat, Keterkaitan Melalui Perjanjian Hak Suara/voting agreement. Dalam hal ini keterkaitan ini muncul karena adanya perjanjian hak suara/voting agreement yang dilakukan oleh para pemegang saham menyetujui untuk penempatan dan penunjukan anggota direksi dan/atau dewan komisaris. Perjanjian hak suara/voting agreement semacan ini terjadi pada perusahaan grup BUMN (Badan Usaha Milik Negara). Kelima, keterkaitan melalui kontrak, yang mana suatu perseroan dapat melimpahkan kendali atas kontrol atau menejemen kepada perseroan lain melalui perjanjian/agreement pengelolaan perusahaan. ${ }^{9}$

Melalui penguasaan saham mayoritas oleh perusahaan induk(parent company) dan keterkaitan dalam kepemimpinan terhadap perusahaan anak (subsidiary), tidak hanya

${ }^{7}$ Harmasandi, P., Nasution, B., \& Devi, K. PERTANGGUNGJAWABAN

PERUSAHAAN INDUK SEBAGAI CORPORATE GUARANTEE TERHADAP ANAK

PERUSAHAAN TERKAIT ADANYA PEMBERIAN FASILITAS KREDIT INVESTASI OLEH

PERBANKAN. TRANSPARENCY, 1(1).

8 Ibid

${ }^{9}$ Ibid 
memberikan kewenangan untuk mengatur suatu kebijakan atau strategi-strategi bisnis dari perusahaan induk (parent company) kepada perusahaan anak (subsidiary) dalam kontruksi perusahaan grup-(holding company), akan tetapi juga juga pengendalian dan dominasi sepenuhnya. Pengendalian dan dominasi sepenuhnya tidak hanya menyangkut aspek keuangan saja, tetapi juga kontrol dalam praktik usaha dan bisnis yang berimplikasi terhadap ketidak kemandirian suatu badan hukum yang menjadi eksistensi dirinya. ${ }^{10}$ Kewenangan suatu perseroan untuk mengendalikan perseroan lainnya menjadi sebab dari keberadaan pimpinannsentral dalam perusahaanngrup(holding company), yang mengakibatkan semua kepentingan perusahaan anak (subsidiary) ditujukan untuk mendukung kepentingan perusahaan grup-(holding company). ${ }^{11}$ Dengan demikian, Pengendalian perusahaan induk-(parent company) terhadap perusahaan anak -(subsidiary) melalui penerapan kebijakan perusahaan induk -(parent company) adalah bersifat faktual dari realitas bisnis perusahaan grup-(holding company) yang dikelola sebagai satu kesatuan ekonomi.

Dominasi dari perusahaan induk (parent company) kepada perusahaan anak (subsidiary) berdampak pada ketidakmandirian perusahaan anak (subsidiary) dalam mejalankan kegiatan ekonominya, sehingga kepengurusan perseroan tidaklah hanya ditujukan kepada perusahaan anak (subsidiary), akan tetapi juga untuk pentingan perusahaan induk (parent company) sebagai satu kesatuan ekonomi dalam kontruksi perusahaan grup-(holding company). Penyalahgunaan kontruksi perusahaan grup oleh perusahaan induk (parent company) ini dapat menimbulkan suatu merugikan pihak ketiga perusahaan anak. Pihak ketiga perusahaan anak yaitu pemegang saham minoritas, pekerja perusahaan anak, maupun kreditur dapat menderita kerugian, dengan adanya fakta pengendalian dan dominasi perusahaan induk(parent company) yang menyebabkan ketidakmandiran secara ekonomi perusahaan anak(subsidiary). Hal ini terjadi karena belum adanya pengaturan atau undang-undangan yang mengatur tentang perusahaan grup-(holding company).

Hukum perseroan masih menjadi bagian dari pengaturan atau undang-undang dari perseroan-perseroan yangttergabung ke dalam kontruksi perusahaan grup (holding company). Hukum perseroan masih mengakui status yuridis badan hukum dari perusahaan induk (parent company) dan perusahaan anak (subsidiary) sebagai subyek hukum yang mandiri. Hal ini sangat menguntungkan perusahaan induk (parent company), karena sebagai badan hukum yang mandiri perusahaan induk (parent company) dan perusahaan anak (subsidiary) berhak menjalankan tindakan hukum sendiri. Oleh karena itu perusahaan induk (parent company) tidak ikut bertanggung jawab atas tindakan hukum yang dijalakan perusahaan anak (subsidiary). Perusahaan induk (parent company) sebagai pemilik saham mayoritas perusahaan anak (subsidiary) mendapatkan perlindungan atas berlakunya prinsip tanggungjawab terbatas perseroan atau yang disebut sebagai prinsip limited liabillity. Prinsip hukum limited liabillity pada pemilik saham termuat dalam ketentuan Pasal 3 Ayat (1) Undang-Undang No.40Tahun2007 Tentang PerseroanTerbatas(PT), bahwa Perusahaani nduk -(parent company) bertanggungjawab hanya yang serbatas nilai saham yang dimiliki pada perusahaan anak (subsidiary), terhadap ketidakmampuan perusahaan (subsidiary) anak dalam menyelesaikan tanggung jawabnya kepada pihak ketiga, sebagai akibat dari

10 Sulistiowati, op.cit, hlm. 35

11 Ibid 
perusahaan anak (subsidiary) menjalakan kebijakan dari perusahaan induk (parent company). ${ }^{12}$

Namu prinsip limited liability tidaklah berlaku mutlak, pada kondisi tertentu pemengan saham atas suatu perseroan terbatas masih dimungkinkan untuk bertanggung jawab atas perbuatan hukum peseroan dan juga terhadap tanggung jawab pemegang saham tidaklah benar-benar terbatas. Hal ini dikenal sebagai prinsip piercing the corporate veil. Piercing the coporate viel merupakan pengecualian atas hapusnya prinsip limited liability pemegang saham perseroan. Prinsip piercing the coporate viel muncul sebagai respon terhadap prinsip limited liability. Prinsip piercing the corporate viel ini mengacu kepada pemegang saham perseroan turut bertanggung jawab atas hutang perseroan yang diterapkan jika perusahaan anak (subsidiary) yang hanya dimanfaatkan sebagai instrument mencapai tujuan untuk memepoleh keuntungan perusahaan induk(parent company). Penerapan dari prinsip piercing the corporate veil di dalam perusahaan grup juga diterapkan apabila perusahaan induk melakukan perbuatan melawan hukum atau tindak pidana. ${ }^{13}$ Prinsip piercing the corporate veil ini juga telah mengalami perkembangan dan memiliki varian yang berguna untuk menjelaskan lebih lanjut dari prinsip piercing the corporate veil. ${ }^{14}$

1. Instrumentally

Difinisi dari prinsip instrumentally adalah dominasi perusahaan induk (parent company) kepada perusahaan anak (subsidiary) terhadap seluruh aspek kegiatan bisnis perusahaan anak (subsidiary) melalui kebijakan yang diterapkan oleh perusahaan induk(parent company), sehingga menyebabkan ketidakmandirian perusahaan anak(subsidiary). Untuk mengetahui upaya penerapan piercing the corporate veil, Freddick J. Powell telah memformulasikan pengujian untuk membuka tabir perseroan dalam konteks kontruksi perusahaan grup melalui tiga tes yang meliputi:

a) Mere instrumentally test adalah tes pertama untuk meninjau apakah perusahaan anak (subsidiary) sepenuhnya berada dibawah dominasi dari perusahaan induk (parent company).

b) Fraud or wrong injustice test adalah tes kedua untuk meninjau apakah dominasi perusahaan induk (parent company) dapat dipegunakan untuk melakukan kecurangan, atau tindakan tidakan melawan hukum terhadap penggugat.

c) Unjust lost injury adalah tes ketiga untuk meninjau apakah penggugat secara nyata telah menderita kerugian sebagai akibat dari tindakan yang dilakukan oleh tergugat.

2. Alter ego

12 Prakoso, D. (2016). Tanggung Jawab Hukum Induk Perusahaan Terhadap Perbuatan Hukum Anak Perusahaannya (Doctoral dissertation, UII). Hlm 90

${ }^{13}$ Sulistyawati, T. T. (2018). EKSISTENSI DOKTRIN “PIERCING THE CORPORATE VEIL" ATAS PELAKSANAAN SENTRALISASI PROCUREMENT ANAK PERUSAHAAN OLEH INDUK PERUSAHAAN. Notaire, 1(1), 174-195.

${ }^{14}$ Siregar, H. M. Y. (2016). Tanggung Jawab Yuridis Atas Tindakan Induk Perusahaan Melakukan Penyertaan Modal Kepada Anak Perusahaan (Studi Kasus Putusan Mahkamah Agung Nomor: 1038/K/PDT. SUS/2010). 
Difinisi dari prinsip alter ego mengarah kepada penggabungan/penyatuan antara kepemilikan/penguasaan dan kepentingan/tujuan dari dua perusahaan terafilisasi yang seharusnya terpisah. Menurut prinsip dari alter ego, penerapan piercing the corporate veil memenuhi unsur sebagai berikut:

a) Terdapatnya penggabungan/penyatuan kepentingan dan kepemilikan / penguasaan, yang berimplikasi terhadap terafiliasi dua perusahaan yang tidak lagi memiliki keterpisahan dan perusahaan anak(subsidiary) menjadi alter ego perusahaan induk

b) Pengakuan terhahap dua perusahaan sebagai badan hukum, yang terpisah sehingga menyababkan terjadinya tidak berkadilan sampai bahkan penipuan.

\section{Agency}

Difinisi dari prinsip agency adalah campur tangan yang begitu dominan/dominasi sepenuhnya. Pada intinya, prinsip agency menunjukan bahwa untuk menghindari metamorfosa dalam keputusan dari prinsip piecing the corporate veil, dalam kasus ketika adanya campur tangan yang begitu dominan/dominasi sepenuhnya dari perusahaan induk(parent company), dan aturan umum keagenan (agency) berlaku dimana relasi perusahaan induk(parent company) menjadi principal, sedangakan perusahaan anak (subsidiary) menjadi agen. Dengan demikian, apabila perusahaan anak (subsidiary) memiliki kewenangan untuk bertindak atas nama perusaahaan induk (parent company) bedasarkan prinsip keagenan atau principal agency, perusahaan induk (parent company) akan bertanggung jawab sebagai principal atas tindakan agennya.

Penerpan prinsip piercing the corporate veil secara eskplisit termuat dalam ketentuan Undang-Undang No.40Tahun2007, Pasal 3 ayat (2) huruf b,c, dan d yaitu: Huruf (b) bahwa pemegang saham yang bersangkutan dalam suatu perseroan terbatas baik secara terbuka atau tidak terbuka dengan etikad buruk memanfaatkan/menggunakan perseroan untuk kepentingan pribadi. Huruf (c) bahwa pemegang saham suatu perseroan terbatas secara terbuka atau tidak terbuka terlibat dalam tindakan merlanggar undang-undang yang dilakukan oleh perseroan. Huruf (d) bahwa secara terbuka atau tidak terbuka melawan undang-undang memanfaatkan/menggunakan harta perseroan, sehingga harta/kekayaan dari perseroan tidak mencukupi untuk menuntaskan hutang perseroan. Apabila telah memenuhi syarat-syarat tersebut maka pembebanan rugi dapat dibebankan kepada perusahaan induk(parent company). Pembebanan tanggung jawab terhadap perusahaan induk(parent company) melalui penerapan kebijakan yang dilaksanakan oleh perusahaan anak(subsidiary) tentunya dilihat dari adanya kesalahan/kelalain dan/atau tindakan melawan hukum yang menyebabkan adanya kkerugian, yang dalam hal ini adalah ada pemanfaatan kewenangan dari perusahaan induk(parent company) untuk memperoleh keutungan tanpa memperhatikan dampak yang ditimbulkan kepada perusahaan anak(subsidiary).

Untuk perluasan pembebanan tanggung jawab atas kebijakan yang diterapkan oleh perusahaan induk (parent company) terhadap perusahaan anak(subsidiary) yang melakukan tindakan hukum sampai dengan timbulnya suatu kerugian, maka dapat menggunakan prinsip tanggungjawab berdasarkan atas kesalahan (fault liability or liability based on fault). Ketentuan prinsip ini termuat didalam Kitab Undang-Undang Hukum Perdata ketentuan pasal 1367 KUHPerdata, Prinsip tanggung jawab 
berdasarkan kesalahan ini baru akan berlaku apabila terpenuhinya unsur kerugian akibat dari adanya suatu kesalahan/kelalaian. ${ }^{15}$ Terpenuhinya unsur kerugian dan tindakan melawan hukum menjadi syarat bagi lahirnya tanggung jawab hukum. Pasal 1367 KUHPeradata, bahwa seseorang tidak hanya bertanggung jawab atas adanya suatu kerugian yang dikarenakan tindakannya sendiri, tetapi juga atas kerugain yang dikarenakan tindakan orang-orang yang menjadi tanggungannya, atau dikarenakan benda-benda yang berada dalam pengawasannya. Ketentua pasal 1367 KUHPerdata merupakan wujud perluasan tanggung jawab hukum perusahaan induk(parent company) terhadap kerugian dari perusahaan-(subsidiary) anak yang menjalankan kebijakan atau intruksi dari perusahaan induk(parent company).

Relasi antara seseorang dan orang-orang yang menjadi tanggungannya ini dapat dianalogikan sebagai kewenangan dari perusahaan induk (parent company) terhadap perusahaan anak-(subsidiary) dalam kontruksi perusahaan grup-(holding company), dimana perusahaan induk (parent company) yang mengokoordinasikan dan mengendalikan perusahaan grup (holding company) melalui penerapan kebijakan yang dijalankan oleh anak perusahaan-(subsidiary) untuk mecapai tujuan kolektif perusahaan grup (holding company) sebagai satu kesatuan ekonomi, sehingga berdampak pada kerugain pihak perusahaan-anak (subsidiary) yang menjalakan kebijakan atau intrusksi dari induk perusahaan-(parent company) tersebut. Seharusnya hal ini dapat mejadikan dasar untuk membebankan tanggung jawab. Perusahaan induk (parent company) dapat dibebani tanggungjawab apabila perusahaan induk (parent company)tersebut terbukti dalam keikut sertaannya dalam menentukan menejemen, keuangan, keputusan bisnis, yang mengakibatkan suatu kerugian kepada perusahaan anak (subsidiary).

\section{2 mengantisipasi pengendalian tanpa tanggung jawab dari perusahaan induk yang berdampak atas kebijakan yang diterapkan kepada perusahaan anak sehingga terhindar dari suatu kerugian.}

Kontruksi perusahaan grup (holding company) terbentuk tidak terlepas dari adanya motif kerjasama yang mengacu pada realitas bisnis yang ditimbulkan dari adanya kerterkaitan antara perusahaan induk (parent company) dan perusahaan anak (subsidiary), sehingga meningkatkan nilai (value) perusahaan grup (holding company), dan meningkatkan keuntungan (revenue) yang sebesar-besarnya. Secara yuridis, pengendalian perusahaan anak(subsidiary) oleh perusahaan induk (parent company) yang merupakan pimpinan sentral di dalam kontruksi perusahaan grup(holding company) dijalankan melalui kepemilikan saham yang signifikan, pengunaan hak suara dalam RUPS anak perusahaan, ataupun melalui pengangkatan anggota direksi dan/atau dewan komisaris anak perusahaan. Perlunya ada batasan atas kewenangan pengendalian perusahaan induk (parent company) dalam penetapan kebijakan strategis pada perusahaan anak(subsidiary) apabila menimbulkan suatu kerugian. Sebagaimana pendapat dari Munir Fuady bahwa sesungguhnya dalam berbagai hal hukum harus mentolerir dominasi perusahaan induk(parent company) kedalam manejemen 
perusahaan anak(subsidiary) sampai batas-batas tertentu, dengan tetap memperhatikan prinsip kemandirian perusahaan anak. ${ }^{16}$

Untuk menghindari pengendalian tanpa tanggung jawab dari perusahaan induk (parent company) kepada prusahaan anak (subsidiary) melalui kebijakan yang diterapkan, maka diperlukan upaya untuk mengantisipasi hal tersebut. Salah satu tindakan yang dapat dijalankan adalah membuat CharterrHubungan KorporasiiDengan Anak Perusahaan. ${ }^{17}$ Charter ini dibentuk untuk mengatur pembagian tugas, wewenang, sinergi, dan koordinasi antara perusahaan induk(parent company) sebagai penanggung jawab dan pengawas usaha kegiatan dengan perusahaan anak(subsidiary), yang merupakan kepenjangan tangan dari perusahaan induk (parent company) dalam menjalakan kebijakan perusahaan induk (parent company) sebagai satu kesatuan ekonomi. ${ }^{18}$ Istilah mengenai Charter atau penggunaan Charter ini, dimaksudkan sebagai dokumen pemeberian kewenangan atau hak istimewa dalam aturan perusahaan yang dapat berupa Anggaran Dasar Perseroan. ${ }^{19}$ Ketentuan mengenai Anggaran Dasar Perseroan termuan di dalam ketetuan Pasal 15 UU No. 30 Tahun 2007 Tentang Perseroan Terbatas(PT).

Sehubungan dengan penerapan Charter ini Gunawa Widjaja berpendapat bahwa Anggaran Dasar Perseroan merupakan bagian penting dari akta pendirian suatu perseroan yang memuat aturan mengenai hubungan internal para pendiri yang terdiri dari pemegang saham, dewan direksi, dewan komisaris dan para anggotanya, namun demikian setelah memperoleh pengesahan dari Mentri Hukum dan Hak Asasi Manusia(MENKUMHAM), Anggaran Dasar Perseroan ini berlaku mengikat sebagai pedoman/undang-undang bagi para pembuatnya. ${ }^{20}$ Jadi dapat disimpulkan bahwa Anggaran Dasar Perseroan merupakan peraturan/aturan yang mengikat untuk setiap orang yang berhubungan dengan perseroan terbatas tersebut. Anggaran Dasar Perseoan biasanya termuat didalam akta pendirian yang dibuat pada waktu mendirikan suatu perseroan terbatas. Kemudian dari pada itu, hal-hal yang dilarang untuk diatur di dalam anggaran dasar perseroan adalah kententuan mengenai perolehan bunga tetappdan pengatruan mengenai penerima manfaat pribadi kepada pendiri perseroan atau pihaklain. Pada awal pendirian peseroan itulah diatur ketentuan terhadap hal-hal yang diperlukan yang tidak dimuat didalam kententuan peraturan perundangundangan di Indonesia dan tidak bertendangan dengan kesusilaan, ketertiban umum, serta peraturan peundang-undangan. Sehingga penggunaan Charter yang dimaksudkan sebagai dokumen pemeberian kewenangan atau hak istimewa dalam aturan perusahaan yang dapat berupa Anggaran Dasar Perseroan ini, diharapkan mampu mengatur batas kewenangan perusahaan induk (parent company) didalam penerapan kebijakan, dan untuk menghindari adanya pelampauan kewenangan perusahaan induk (parent company) dalam mengendalikan perusahaan anak (subsidiary).

\footnotetext{
${ }^{16}$ Munir Fuady,2008, Hukum Perusahaan Dalam Paradigma Hukum Binis Berdsasarkan Undang-Undang Nomo4 40 Tahun 2007, PT Citra Aditya Bakti,Bandung, hlm. 86

17 Tri Julyanto, (2011). Analisis Yuridis Penerapan Charter Hubungan Korporasi Dengan Dan

Antar Anak Perusahaan. Universitas Indonesia, hlm 2

18 Ibid

19 Ibid, hlm. 36

${ }^{20}$ Gunawan Widjaja, 150 Tanya Jawab Tentang Perseroan Terbatas- Seri Pemahaman

Perseroan Terbatas, Forumsahabat, Jakarta, hlm. 6
} 
Pembatasan tanggung jawab tersebut dapat juga diatur didalam perjianjian tesendiri, terhadap keseluruhan proses dan prosedur penerapan kebijakan sentralisasi pengadaan barang dan/atau jasa (procument) perusahaan anak(subsidiary), dimana tanggung jawab perusahaan induk(parent company) adalah melaksanakan keseluruhan prosedur procument namun tidak termasuk proses penentuan pengadaan barang dan/atau jasa yang menjadi kewenangan perusahaan anak sebagai bentuk dari prinsip kemandirian perusahaan anak. Menurut pendapat dari Suliowati, bahwa diperlukannya suatu perjanjian pengendalian antara perusahaan induk (parent company) dan perusahaan anak(subsidiary), terhadap dimungkinkannya dominasi perusahaan induk(parent company), sehingga perusahaan anak(subsidiary) hanya dijadikan instrument oleh perusahaan induk (parent company) untuk mencapai tujuan kolektif perusahaan grup(holding company). Maka melalui hubungan kontrak ini apabila terjadi sengketa di pengadilan maka perusahaan induk(parent company) wajib bertanggungjawab atas kerugian pihak ketiga perusahaan anak dan tidak diperlukannya bukti di pengadilan terhadap ada atau/tidaknya dominasi/pengendalian penuh dari perusahaan induk (parent company) terhadap perusahaan anak (subsidiary).

Implikasi yuridisnya adalah tanggung jawab induk perusahaan(parent company) terhadap adanya suatu kerugian pihak ketiga dari anak perusahaan yang menjalakan kebijakan atau intruksi dari perusahaan indukk (parent company). ${ }^{21}$ Dominasi perusahaan indukk(parent company) terhadap anak perusahaan(subsidiary) merupakan persyaratan berlakunya hubungan kontraktual ini. Memorial penjelasan Pasal 4 Undang-Undang Nomor 40 Tahun 2007 tentang Perseroan Terbatas telah memuat spirit untuk mengantisipasi peluang adanya penyalahgunaan badan hukum perseroan. Pasal tersebut menentukan bahwa berlakunya undang-undang teserbut diatas, anggaran dasar perseroan terbatas, dan ketentuan perundang undang-undang lain, tidak mengesampinkan kewajiban untuk setiap perseroan mentaati asas etikad baik, asas kepatutan, asas kepantasan, dan prinsip tata kelola perseroan yang baik atau good corporate gorvanance dalam menjalankan perseroan. Ketentuan Pasal 4 Undang-Undang Nomor 40 Tahun 2007 maupun memori penjelasannya ini berlaku secara mutatis mutandis terhdap penyalahgunaan anak perusahaan(subsidiary) dalam kontruksi perusahaan grup (holding company). Dengan demikian, relasi perusahaan induk(parent company) dan perusahaan anak(subsidiary) dalam kontruksi perusahaan grup(holding company) haruslah menaati prinsip tata kelola perseroan yang baik atau good corporate governance. Dengan menggunakan pendekatan good corporate governace, perusahaan induk(parent company) memiliki kewenangan untuk mengendalikan dan mengkoordinasikan perusahaan anak(subsidiary) pada kepentingan strategis perusahaan grup(holding company), sepanjang tidak mendominasi terhadap kepengurusan sehari-hari perusahaan anak subsidiary) yang menyebabkan perusahaan anak(subsidiary) kehilangan kemandirian yuridis sebagai subjek hukum yang berhak melakukan perbuatan hukum sendiri.

\section{Kesimpulan}

Pembebanan tanggung jawab pada perusahaan induk(parent company) adalah untuk memberikan perlindungan hukum kepada pihak tiga perusahaan anak(subsidiary) yang terdiri dari pemegang saham minoritas, pekerja perusahaan anak, maupun kreditur. Prinsip tanggung jawab perusahaan induk(parent company) dalam konturksi perusahaan

\footnotetext{
${ }^{21}$ Sulistiowati, op cit, hlm. 46
} 
grup (holding company) hanya sebesar saham yang dimilikinya, hal ini karena berlakunya prinsip limited liability. Namun kemudian prinsip piercing the coporate viel muncul sebagai respon terhadap prinsip limited liability. Prinsip piercing the corporate viel mengacu kepada pemegang saham perseroan turut bertanggung jawab atas hutang perseroan dan diterapkan jika anak perusahaan hanya dimanfaatkan sebagai instrument mencapai tujuan untuk memepoleh keuntungan pribadi pemagang saham. Penerpan prinsip piercing the corporare veil secara eskplisit termuat dalam ketentuan Undang-Undang Nomor 40 Tahun 2007, Pasal 3 ayat (2) huruf b,c, dan d. Untuk perluasan pembebanan tanggung jawab atas kebijakan yang diterapkan oleh perusahaan induk(parent company) kepada anak perusahaan(subsidiary) sehingga berakibat timbulnya suatu kerugian, dapat menggunakan prinsip tanggung jawab berdasarkan kesalahan (fault liability or liablity based on fault). Ketentuan prinsip ini termuat dalam Kitab Undang-Undang Hukum Perdata di dalam Pasal 1365, 1366, dan 1337.

Perlunya ada batasan atas kewenangan pengendalian perusahaan induk (parent company) dalam penetapan kebijakan strategis pada perusahaan anak(subsidiary) apabila menimbulkan suatu kerugian. Salah satu tindakan yang dapat dilakukan adalah pembentukan Charter Hubungan Korporasi Dengan Anak Perusahaan. pembuatan charter ini dimaksudkan sebebagi dokumen pemeberian kewenangan dan atau hak istimewa yang dapat berupa Anggaran Dasar Perseroan. Charter ini dibentuk untuk mengatur pembagian tugas, wewenang, sinergi, dan koordinasi antara perusahaan induk(parent company) sebagai penanggung jawab dan pengawas usaha dan/atau kegiatan dengan perusahaan anak, yang dalam hal ini merupakan kepenjangan tangan(operating arm) dari perusahaan induk(parent company) dalam pelaksanaan oprasional ataupun pencapain strategi perusahaan induk(parent company). Sedangkan pendapat dari Sulistiowati, bahwa diperlukannya suatu perjanjian pengendalian antara perusahaan induk(parent company) dan perusahaan anak(subsidiary), terhadap dimungkinkannya dominasi perusahaan induk(parent company), sehingga perusahaan anak(subsidiary) hanya menjadi instrument perusahaan induk(parent company) untuk mencapai tujuan kolektif perusahaan grup (holding company). Sehingga apabila terjadi sengketa di pengadilan maka perusahaan induk wajib(parent company) bertanggung jawab atas kerugian pihak ketiga anak perusahaan dan tidak diperlukannya bukti di pengadilan terhadap ada atau/tidaknya dominasi perusahaan induk(parent company) terhadap anak perusahaan(subsidiary). Implikasi yuridisnya adalah tanggung jawab perusahaan induk(parent company) terhadap adanya suatu kerugian pihak ketiga dari perusahaan anak yang menjalakan kebijakan atau intruksi dari perusahaa induk(parent company).

Daftar Pustaka / Daftar Referensi

Buku :

Bonifaius Aji Kuswantoro, 2016, Keuntungan \& Resiko Menjadi Direktur, Komisari, Dan Pemegang Saham, PT Visimedia Pustaka, Jakarta.

Gunawan Widjaja, 150 Tanya Jawab Tentang Perseroan Terbatas- Seri Pemahaman Perseroan

Terbatas, Forumsahabat, Jakarta. 
Munir Fuady,2008, Hukum Perusahaan Dalam Paradigma Hukum Binis Berdsasarkan Undang-

Undang Nomo4 40 Tahun 2007, PT Citra Aditya Bakti, Bandung.

Sulistiowati, 2013, Tanggung Jawab Hukum Pada Perusahaan Grup Di Indonesia, Erlangga, Jakarta.

Jurnal :

Harmasandi, P., Nasution, B., \& Devi, K. PERTANGGUNGJAWABAN PERUSAHAAN INDUK SEBAGAI CORPORATE GUARANTEE TERHADAP ANAK PERUSAHAAN TERKAIT ADANYA PEMBERIAN FASILITAS KREDIT INVESTASI OLEH PERBANKAN. TRANSPARENCY, 1(1).

Sulistiowati, S. (2012). Doktrin-doktrin Hukum mengenai Tanggung Jawab Hukum dalam Perusahaan Grup. Jurnal Hukum Bisnis

Sulistyawati, T. T. (2018). EKSISTENSI DOKTRIN "PIERCING THE CORPORATE VEIL" ATAS PELAKSANAAN SENTRALISASI PROCUREMENT ANAK PERUSAHAAN OLEH INDUK PERUSAHAAN. Notaire, 1(1), 174-195.

SYAFI'I, M. U. H. A. M. M. A. D. (2016). PIERCING THE CORPORATE VEIL TERHADAP HOLDING COMPANY DALAM TINDAKAN HUKUM ANAK PERUSAHAAN.

Tesis/Disertasi :

Prakoso, D. (2016). Tanggung Jawab Hukum Induk Perusahaan Terhadap Perbuatan Hukum Anak Perusahaannya (Doctoral dissertation, UII).

Siregar, H. M. Y. (2016). Tanggung Jawab Yuridis Atas Tindakan Induk Perusahaan Melakukan Penyertaan Modal Kepada Anak Perusahaan (Studi Kasus Putusan Mahkamah Agung Nomor: 1038/K/PDT. SUS/2010).

Tri Julyanto, (2011). Analisis Yuridis Penerapan Charter Hubungan Korporasi Dengan Dan Antar Anak Perusahaan. Universitas Indonesia.

Peraturan Perundang Undangan-Undangan :

Kitab Undang-Undang Hukum Perdata Republik Indonesia.

Undang-Undang Negara Republik Indonesia Nomor 30 Tahun 2007 tentang Perseroan Terbatas (Lembaran Negara Republik Indonesia Nomor 8 Tahun 2007 Nomor 106). 